\title{
Impact of carbonate saturation on large Caribbean benthic foraminifera assemblages
}

\author{
Ana Martinez ${ }^{1}$, Laura Hernández-Terrones ${ }^{2}$, Mario Rebolledo-Vieyra ${ }^{3}$, and Adina Paytan ${ }^{4}$ \\ ${ }^{1}$ Department of Earth and Planetary Sciences, University of California Santa Cruz, 1156 High Street, \\ Santa Cruz, CA 95064, USA \\ ${ }^{2}$ Universidad del Caribe, L-1. Mz 1, Esq. Fracc. Tabachines SM 78, Cancún, Quintana Roo, 77528, Mexico \\ ${ }^{3}$ Chipre 5, Resid. Isla Azul, Cancún, Quintana Roo, 77500, Mexico \\ ${ }^{4}$ Institute of Marine Science, University of California Santa Cruz, Santa Cruz, CA 95064, USA
}

Correspondence: Adina Paytan (apaytan@ucsc.edu)

Received: 12 July 2018 - Discussion started: 16 July 2018

Revised: 26 October 2018 - Accepted: 29 October 2018 - Published: 16 November 2018

\begin{abstract}
Increasing atmospheric carbon dioxide and its dissolution in seawater have reduced ocean $\mathrm{pH}$ and carbonate ion concentrations, with potential implications on calcifying organisms. To assess the response of large Caribbean benthic foraminifera to low carbonate saturation conditions, we analyzed benthic foraminifers' abundance and relative distribution in surface sediments in proximity to low-carbonatesaturation submarine springs and at adjacent control sites. Our results show that the total abundance of large benthic foraminifera was significantly lower at the low-pH submarine springs than at control sites, although responses were species specific. The relative abundance of high-magnesium, porcelaneous foraminifera was higher than that of hyaline foraminifera at the low-pH springs due to the abundant Archaias angulatus, a chlorophyte-bearing foraminifer, which secretes a large and robust test that is more resilient to dissolution at low-calcite saturation. The different assemblages found at the submarine springs indicate that calcareous symbiont-barren foraminifera are more sensitive to the effects of ocean acidification than agglutinated and symbiontbearing foraminifera, suggesting that future ocean acidification will likely impact natural benthic foraminifera populations.
\end{abstract}

\section{Introduction}

Anthropogenic activities such as deforestation and fossil fuel burning are increasing the concentration of carbon dioxide $\left(\mathrm{CO}_{2}\right)$ in the atmosphere. About one third of all the $\mathrm{CO}_{2}$ emitted into the atmosphere by humans over the past 200 years has been absorbed by the oceans (Sabine et al., 2004), causing a change in ocean chemistry, lowering the $\mathrm{pH}$ and the concentration of carbonate ions in seawater, collectively referred to as ocean acidification. It is expected that ocean $\mathrm{pH}$ will decrease even more, by $\sim 0.4 \mathrm{pH}$ units by year 2100 (Caldeira and Wickett, 2003; Orr et al., 2005) with possible consequences to marine organisms and ecosystems (Raven et al., 2005). Marine calcifying organisms may be particularly sensitive due to the lower availability of carbonate ions, which are required for their shell formation (Raven et al., 2005).

Foraminifera are single-celled organisms that are abundant in the marine water column and sediments, playing key roles in many marine ecosystems, including being basal contributors to the marine food web and essential elements of the marine carbonate pump (Legendre and Le Fèvre, 1995; Culver and Lipps, 2003; Hain et al., 2014). Calcareous foraminifera produce calcium carbonate tests of diverse shapes and thickness, while agglutinated foraminifera build a test made of detrital particles, and thecate foraminifera lack a test. The calcification pathway and magnesium content of calcareous foraminifera varies between perforate hyaline and imperforate porcelaneous foraminifera (Brasier, 1980). Some large benthic foraminifera harbor photosynthetic algal symbionts, 
while others rely solely on heterotrophic feeding (Murray, 1991). The diversity of lifestyles and test characteristics suggest that the sensitivity of this group of organisms to changing ocean carbonate chemistry will be species dependent (Fabry et al., 2008; Fujita et al., 2011).

Laboratory culture experiments where benthic foraminifera were maintained under controlled conditions (i.e., partial pressure of $\mathrm{CO}_{2}$, alkalinity, etc.) generally showed a decline in foraminifera calcification under high $p \mathrm{CO}_{2}$ (Erez, 2003; Haynert et al., 2011; Keul et al., 2013). However, this response was not uniform and varied among species (Fujita et al., 2011; Hikami et al., 2011; McIntyre-Wressnig et al., 2013). Field studies at $\mathrm{CO}_{2}$ vents in the Pacific Ocean (Fabricius et al., 2011; Uthicke et al., 2013) and Mediterranean Sea (Dias et al., 2010) reported a decrease in benthic foraminiferal abundance with increasing $p \mathrm{CO}_{2}$, especially of calcareous species; nonetheless benthic foraminifera have been found living near $\mathrm{CO}_{2}$ vents in the northern Gulf of California (Pettit et al., 2013) and near experimentally injected deep-sea $\mathrm{CO}_{2}$ hydrate (Bernhard et al., 2009), and generally, foraminifera can be found in a wide range of environments (Brasier, 1980).

To shed light on the potential response of large Caribbean benthic foraminifera to a future increase in $\mathrm{CO}_{2}$ concentration and an associated decrease in $\mathrm{pH}$ and carbonate ion concentrations, we studied the absolute and relative abundance of large benthic foraminifera around a series of submarine springs that naturally discharge low-carbonatesaturation-state $(\Omega)$ saline groundwater in the Yucatán Peninsula, Mexico (Crook et al., 2012). The Yucatán Peninsula is a karstic region with extensive nearshore submarine groundwater springs that discharge water characterized by low $\mathrm{pH}$, high total inorganic carbon, and total alkalinity, but it has only slightly lower salinity and similar temperatures to local marine conditions (Hofmann et al., 2011; Crook et al., 2012, 2013, 2016; Paytan et al., 2014; Null et al., 2014). Previous studies have determined that the springs have been discharging low- $\Omega$ water for millennia (Back et al., 1979); therefore, they serve as a natural laboratory to study the in situ responses of marine organisms and ecosystems to long-term exposure to low $\Omega$, which may not be captured in short-term experiments (Andersson et al., 2015). Field studies from this site reported reduced coral species richness and coral colony size at the springs, compared to control sites (Crook et al., 2012), and a $70 \%$ smaller cover of calcifying benthic organisms after 14 months of a recruitment experiment (Crook et al., 2016). We hypothesize that benthic foraminifera assemblages will also differ between the springs and control sites, decreasing in overall abundance and having distinct species composition depending on test type, magnesium content, feeding strategy, and the photosymbiotic associations of foraminifera.

\section{Materials and methods}

\subsection{Field sampling}

Benthic foraminifera from the upper centimeter of sediment were collected in October 2011 near five submarine groundwater springs (Norte, Mini, Pargos, Laja, and Gorgos) at Puerto Morelos reef lagoon (National Marine Park), in the Mexican Caribbean coast off of Quintana Roo (Fig. 1). At each spring site, five replicates of surface sediment samples (coarse sand) were collected using a spoon into centrifuge tubes, from near the center of the submarine spring and at five control sites about two meters away from each spring, outside the impact area of the spring. Water samples were also collected at each site.

\subsection{Water chemistry}

Water temperature and $\mathrm{pH}$ were measured in situ with a handheld YSI analyzer (Yellow Springs model 63). Seawater samples were filtered $(0.2 \mu \mathrm{m}$ filter) and split into aliquots for total inorganic carbon $\left(\mathrm{C}_{\mathrm{T}}\right)$, total alkalinity $\left(A_{\mathrm{T}}\right)$, and salinity measurements following the standard operating procedures described by Dickson et al. (2007). Total inorganic carbon was analyzed on a CM5011 Carbon Coulometer (UIC, Inc.; analytical measurement error: $\pm 3 \mu \mathrm{mol} \mathrm{kg}^{-1}$ ). Total alkalinity was measured using an automated open-cell, potentiometric titrator (Orion model 950; analytical measurement error: $\pm 2 \mu \mathrm{mol} \mathrm{kg}^{-1}$ ). Certified $\mathrm{CO}_{2}$ reference material (from A. Dickson lab at UC San Diego, batch 112) was used to calibrate the instruments. Salinity was analyzed using a portable salinometer (Portasal Model 8410, Guild Line). The program $\mathrm{CO}_{2}$ Sys (Pierrot et al., 2006) was used to calculate $\mathrm{pH}$, carbonate ion concentrations, and the $\Omega$ of seawater $\left(\mathrm{CO}_{2}\right.$ dissociation constants - Lueker et al., 2000; $\mathrm{KHSO}_{4}$ - Dickson, 2007; B concentration - Uppström, 1974).

\subsection{Foraminiferal analysis}

Five replicate sediment samples per site were freeze dried, weighed, washed with deionized water through a $63 \mu \mathrm{m}$ sieve to remove clay and silt, dried at $50^{\circ} \mathrm{C}$, and the $>250 \mu \mathrm{m}$ fraction was analyzed under an optical microscope (Bausch and Lomb) to determine foraminiferal abundance measured as individuals per gram of sediment. The $>250 \mu \mathrm{m}$ fraction contains the assemblage of adult individuals that are likely to be conserved in the sediment (Martin, 1986). Small juveniles of species dominating the shallow coastal setting have high mortality rates (pre-reproductive death rate of $99.5 \%$ for A. angulatus - Knorr et al., 2015; >99\% for Amphistegina spp. - Muller, 1974), and mortality rates of large foraminifera drop once their diameter is $\sim 0.5 \mathrm{~mm}$ (Hallock and Glenn, 1986). Specifically, in our samples the $>250 \mu \mathrm{m}$ fraction typically constituted $>80 \%$ of the total tests in a sample. Indeed, large-size foraminifera are typical to warm, oligotrophic, well-lit, shallow-water assemblages (Hallock, 


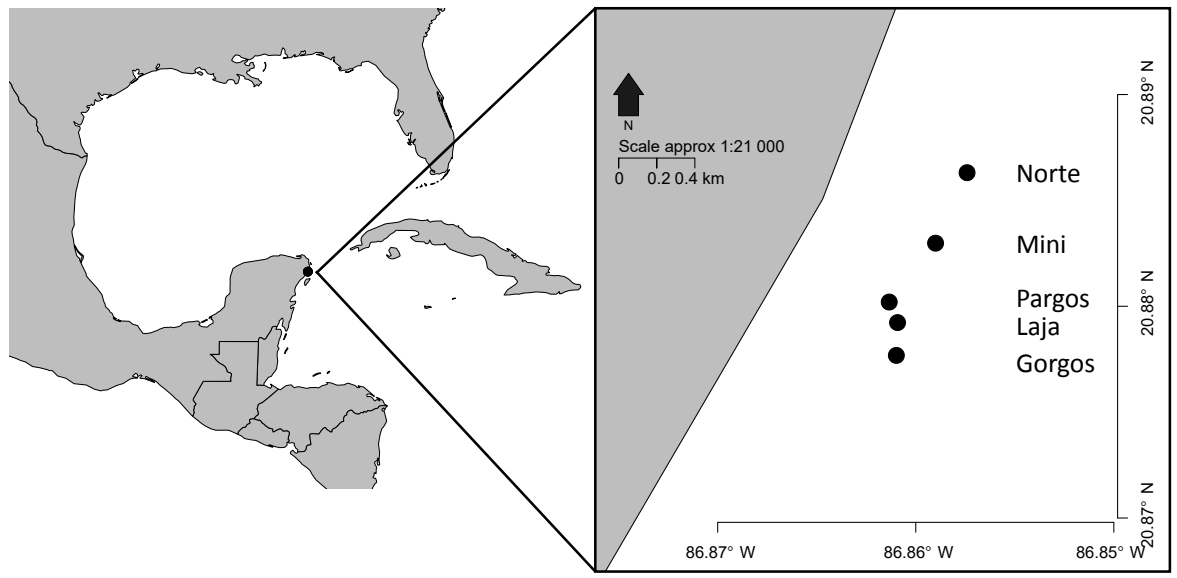

Figure 1. Location of submarine springs at the sampling site.

1985). At least $1 \mathrm{~g}$ of sediment per replicate was analyzed (with $2 \mathrm{~g}$ per replicate for most samples). At least 300 individuals per replicate were counted; however, in 24 of the 50 samples less than 300 individuals per replicate were counted due to low foraminifera abundance. Foraminifera were identified following several taxonomic references (d'Orbigny, 1839; Poag, 1981; Wantland, 1967; Crevison and Hallock, 2001); each individual within a genus was counted and total foraminiferal and genus abundances were normalized to sediment weight. Only the most common genera ( $>5 \%$ of the assemblage in $10 \%$ of the samples) were counted and considered for statistical analyses.

\subsection{Test weight}

Tests of Discorbis rosea from the $250-355 \mu \mathrm{m}$ sediment size fraction ( 2 to 122 individuals) were weighted using an analytical microbalance (Sartorius, model CP2P, $\pm 5 \mu$ g error), and average weight per specimen was determined. This species was chosen because of its abundance in most of the samples and the relatively constant test size.

\subsection{Statistical analysis}

Data analysis and visualization were performed using $\mathrm{R}$ program version 3.4.3 (Team 2017) and the "vegan" package in R (Oksanen et al., 2013). A non-parametric Mann-Whitney rank sum test was conducted to determine differences in foraminiferal abundance and weight between each low- $\Omega$ submarine spring and its corresponding control site. A permutational multivariate analysis of variance (PERMANOVA, 9999 permutations) was used on the Bray-Curtis dissimilarity matrix after the square-root-transformed relative abundance of foraminifera to test for differences in community structure between saturation states and sites. Similarity percentages analysis (SIMPER) was used to determine the most important genera that contributed to dissimilarities in community structure. Non-metric multidimensional scal- ing (nMDS) ordination was used to visualize the similarity in foraminiferal assemblages among $\Omega$ levels and sites. nMDS plots were created with the metaMDS function on the Bray-Curtis dissimilarity matrix of foraminiferal relative abundances and constrained to two dimensions. To evaluate the effects of environmental variables on foraminiferal relative abundance, the log-transformed water chemistry data were overlaid using the envfit function of the vegan library (Dixon, 2003) with 9999 permutations.

\section{Results}

\subsection{Water chemistry}

The $\Omega$, pH, and salinity of water in all springs was lower than their corresponding control sites (Table 1), while alkalinity $\left(A_{\mathrm{T}}\right)$ and total inorganic carbon $\left(\mathrm{C}_{\mathrm{T}}\right)$ were higher than control sites. Temperature $(T)$ was similar at all locations. These data represent the analyses of discrete water samples collected during sediment sampling; more data, including continuous data collected by deployed sensors at some of these sites, have been previously published (Crook et al., 2012, 2013, 2016; Null et al., 2014; Paytan et al., 2014; Hofmann et al., 2011), and data reported here are within the range of the published data. The specific spring sites were selected, because the salinity at these sites is $>30$ over $90 \%$ of the time and does not drop below 27; when salinity drops below 30 ( $7 \%$ of the time), the low-salinity exposure lasts for very short periods of time, always less than $1 \mathrm{~h}$ (Crook et al., 2013)

\subsection{Absolute abundance of foraminifera}

The absolute abundance of foraminifera measured as total number of individuals per gram of sediment was higher at high $-\Omega$ control sites than at low- $\Omega$ springs in Norte $(W=$ $25, p<0.01)$, Mini $(W=25, p<0.01)$, Pargos $(W=25$, 
Table 1. Carbonate chemistry parameters of discrete water samples collected at low-saturation-state submarine springs and adjacent highsaturation-state control sites (mean $\pm \mathrm{SD}$ ) at the time of sample collection $\left(A_{\mathrm{T}}=\right.$ total alkalinity; $\mathrm{C}_{\mathrm{T}}=$ total inorganic carbon).

\begin{tabular}{|c|c|c|c|c|c|c|c|c|c|}
\hline Site & $\begin{array}{r}\text { Depth } \\
(\mathrm{m})\end{array}$ & & $\begin{array}{r}A_{\mathrm{T}} \\
\left(\mu \mathrm{mol} \mathrm{kg}{ }^{-1}\right)\end{array}$ & $\begin{array}{r}\mathrm{C}_{\mathrm{T}} \\
\left(\mu \mathrm{mol} \mathrm{kg^{-1 }}\right)\end{array}$ & $\mathrm{pH}^{\mathrm{a}}$ & $\begin{array}{r}\mathrm{CO}_{3}^{2-\mathrm{a}} \\
\left(\mu \mathrm{mol} \mathrm{kg}{ }^{-1}\right)\end{array}$ & $\begin{array}{r}\Omega^{\mathrm{a}} \\
\text { calcite }\end{array}$ & $\begin{array}{r}T \\
\left({ }^{\circ} \mathrm{C}\right)\end{array}$ & Salinity \\
\hline \multirow[t]{2}{*}{ Norte } & \multirow[t]{2}{*}{5.8} & Control & $2354 \pm 13$ & $2051 \pm 6$ & 7.98 & 216.16 & 5.14 & 27.0 & 36.80 \\
\hline & & Spring & $2611 \pm 3$ & $2588 \pm 3$ & 7.38 & 67.03 & 1.66 & 27.5 & 32.21 \\
\hline \multirow[t]{2}{*}{ Mini } & \multirow[t]{2}{*}{4.9} & Control & $2356 \pm 3$ & $2049 \pm 6$ & 7.99 & 218.13 & 5.16 & 26.4 & 37.3 \\
\hline & & Spring & $3108 \pm 10$ & $3197 \pm 6$ & 7.13 & 46.29 & 1.14 & 27.6 & 32.41 \\
\hline \multirow[t]{2}{*}{ Pargos } & \multirow[t]{2}{*}{6.8} & Control & $2336 \pm 4$ & $2012 \pm 12$ & 8.01 & 229.56 & 5.49 & 27.6 & 36.17 \\
\hline & & Spring & $3000 \pm 8$ & $3048 \pm 12$ & 7.23 & 52.73 & 1.33 & 27.6 & 29.95 \\
\hline \multirow[t]{2}{*}{ Laja } & \multirow[t]{2}{*}{5.8} & Control & $2357 \pm 6$ & $2092 \pm 1$ & 7.90 & 193.55 & 4.63 & 28.1 & 36.17 \\
\hline & & Spring & $2827 \pm 9$ & $2756 \pm 10$ & 7.51 & 102.65 & 2.50 & 27.9 & 32.75 \\
\hline \multirow[t]{2}{*}{ Gorgos } & \multirow[t]{2}{*}{7.2} & Control & $2325 \pm 3$ & $2033 \pm 3$ & 7.96 & 209.44 & 5.02 & 27.8 & 35.90 \\
\hline & & Spring & $2874 \pm 11$ & $2987 \pm 8$ & 7.11 & 94.65 & 2.38 & 28.5 & 31.09 \\
\hline
\end{tabular}

${ }^{\mathrm{a}}$ Calculated using $\mathrm{CO}_{2}$ Sys.

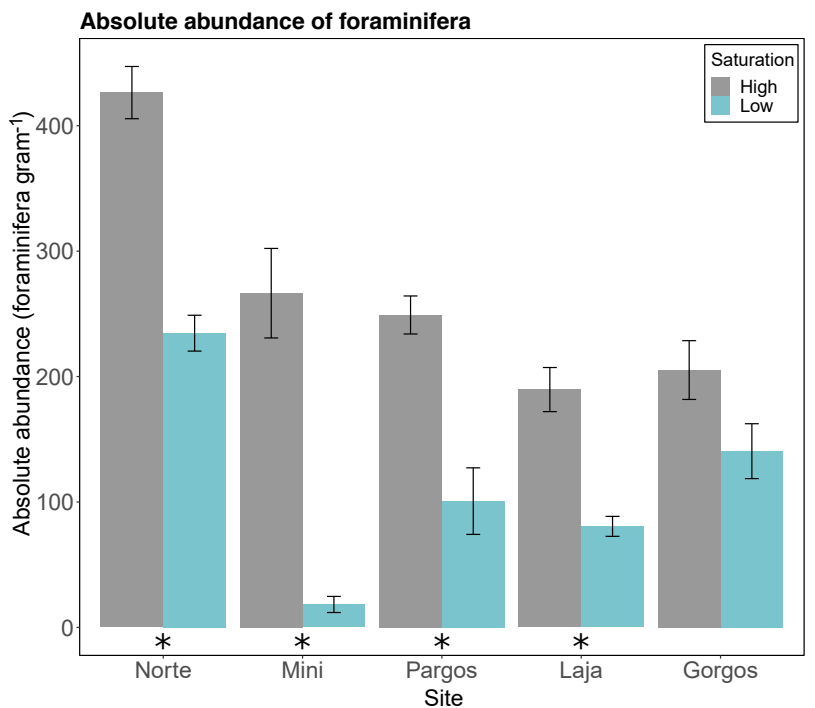

Figure 2. Absolute abundance of foraminifera (number of specimens per gram of sediment) in different submarine springs (lowsaturation state) and their respective control sites (high-saturation state). Data are represented in mean $\pm \operatorname{SE}(n=5)$. The asterisk demarks a significant difference $(p<0.05)$ in abundance between paired springs and controls at each site, according to the MannWhitney rank sum test.

$p<0.01)$, and Laja $(W=25, p<0.01)$, but not in Gorgos $(W=21, p=0.095$; Fig. 2).

\subsection{Genus assemblage}

The seven most abundant genera were: Amphistegina, Archaias, Asterigerina, Quinqueloculina, Triloculina, Discorbis, and Gaudryina. Other foraminifera that were present in some of the samples at a smaller abundance $(<5 \%$ of assem- blage) belong to the following genera: Borelis, Clavulina, Elphidium, Spiroloculina, Peneroplis, Laevipeneroplis, Planorbulina, Sorites, Vertebralina, and Heterostegina. The composition of foraminifera communities (relative abundance of genera) changed significantly between saturation states $\left(\right.$ PERMANOVA $\left._{\text {saturation }}: \mathrm{F}_{1,50}=12.11, p<0.0001\right)$ and between sites (PERMANOVA site $\mathrm{F}_{4,50}=8.15, p<0.0001$ ). A SIMPER analysis revealed that Archaias and Discorbis genera contributed the most to dissimilarities in community structure between low $\Omega$ and high $\Omega$ in most of the sites, while Asterigerina contributed the most in Pargos (Fig. 3). Archaias relative abundance increased at low $\Omega$, and Discorbis and Asterigerina relative abundances decreased at low $\Omega$ in all sites. The combined relative abundance of Amphistegina and Gaudryina increased at low $\Omega$ in all sites but Norte. Quinqueloculina and Triloculina combined relative abundance decreased at low $\Omega$ in Pargos, Laja, and Gorgos and increased in Norte and Mini.

\subsection{Foraminifera test type}

Foraminifera were divided into three groups to investigate abundance differences based on test type. The calcareous porcelaneous group included Archaias angulatus and several species of Quinqueloculina and Triloculina genera. The calcareous hyaline group included Amphistegina, Asterigerina, and Discorbis. The non-calcareous agglutinated group included individuals of the genus Gaudryina. Porcelaneous absolute abundance was lower at low $\Omega$ at all sites but Gorgos (see Fig. 4 - Norte: $W=23, p<0.05$; Mini: $W=25$, $p<0.01$; Pargos: $W=25, p<0.01$; Laja: $W=25, p<0.01$; Gorgos: $W=20, p=0.151)$. Hyaline absolute abundance was lower at low $\Omega$ at all sites (Norte: $W=25, p<0.01$; Mini: $W=25, p<0.01$; Pargos: $W=25, p<0.01$; Laja: $W=25, p<0.01$; Gorgos: $W=25, p<0.01)$. The abso- 

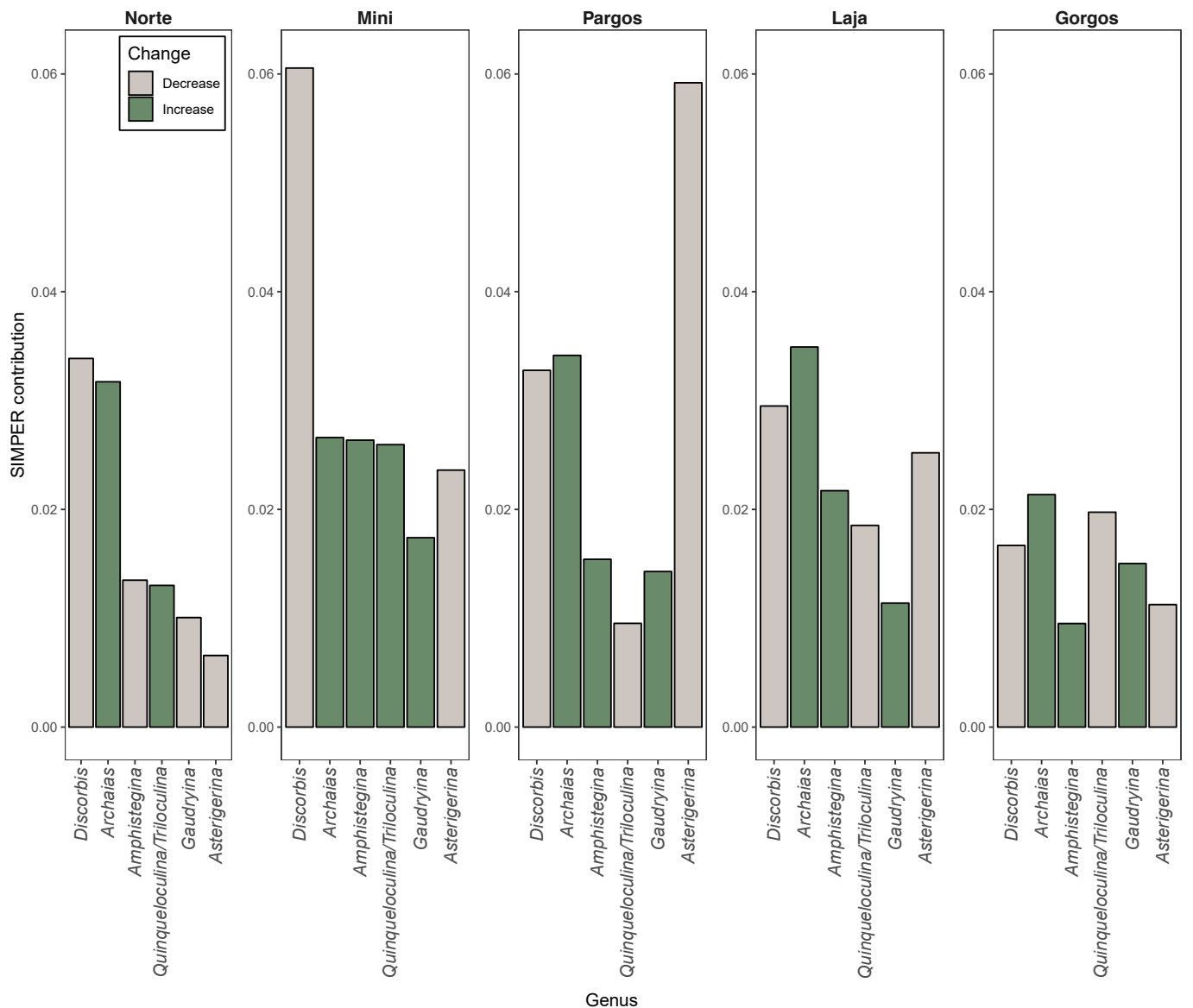

Figure 3. SIMPER contribution of the most abundant genera. Bar height indicates the mean contribution of each genus to community dissimilarity. Green color represents an increase and grey color represents a decrease in the mean relative abundance of each genus at low-saturation springs.

lute abundance of agglutinated foraminifera was lower at low $\Omega$ than at high $\Omega$ in Norte $(W=24, p<0.05)$ and Mini $(W=25, p<0.01)$ and did not vary with $\Omega$ in Pargos $(W=16, p=0.548)$, Laja $(W=21, p=0.095)$, and Gor$\operatorname{gos}(W=11, p=0.841)$.

The relative abundance of foraminifera measured as a percentage of each group within the population also differed between $\Omega$ conditions (Fig. 4). Porcelaneous relative abundance was higher at low $\Omega$ in Norte and Laja (Norte: $W=$ $0, p<0.01$; Mini: $W=5, p=0.151$; Pargos: $W=5, p=$ 0.151 ; Laja: $W=0, p<0.01$; Gorgos: $W=5, p=0.142$ ). In contrast, the hyaline relative abundance was lower at low $\Omega$ in Norte and Laja (Norte: $W=25, p<0.01$; Mini: $W=$ 20, $p=0.142$; Pargos: $W=20, p=0.151$; Laja: $W=25$, $p<0.01$; Gorgos: $W=20, p=0.151)$. The relative abundance of agglutinated foraminifera was higher at low $\Omega$ in Laja $(W=2, p<0.05)$ and did not vary with $\Omega$ in the other four sites (Norte: $W=16, p=0.548$; Mini: $W=6$, $p=0.222$; Pargos: $W=3, p=0.056$; Gorgos: $W=7, p=$ 0.310 ).

\subsection{Effect of magnesium content in test of calcareous foraminifera}

Calcareous foraminifera were divided into three groups based on the magnesium $(\mathrm{Mg})$ content of their test to evaluate the effect of $\mathrm{Mg}$-dependent solubility on abundance. Foraminifera were grouped into low-Mg-content (Discorbis), intermediate-Mg-content (Amphistegina and Asterigerina), and high-Mg-content (Archaias, Quinqueloculina and Triloculina) tests. The absolute abundance of foraminifera with a low-Mg test was lower at low $\Omega$ in all sites (see Fig. 5 - Norte: $W=25, p<0.01$; Mini: $W=25, p<0.01$; Pargos: $W=25, p<0.01$; Laja: $W=25, p<0.01$; Gorgos: $W=25, p<0.01)$. Similarly, the absolute abundance of intermediate- $\mathrm{Mg}$ foraminifera was lower at low $\Omega$ in all sites (Norte: $W=25, p<0.01$; Mini: $W=25, p<0.01$; Pargos: $W=25, p<0.01$; Laja: $W=25, p<0.01$; Gorgos: $W=23$, $p<0.05)$. The absolute abundance of high-Mg foraminifera was lower at low $\Omega$ at all sites but Gorgos (Norte: $W=23$, $p<0.05$; Mini: $W=25, p<0.01$; Pargos: $W=25, p<0.01$; Laja: $W=25, p<0.01$; Gorgos: $W=20, p=0.151$ ). 

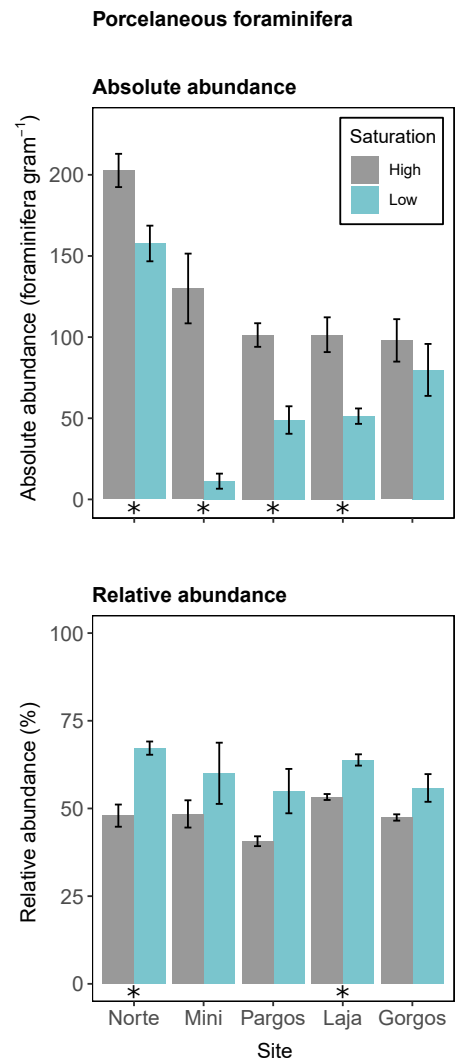

Hyaline foraminifera

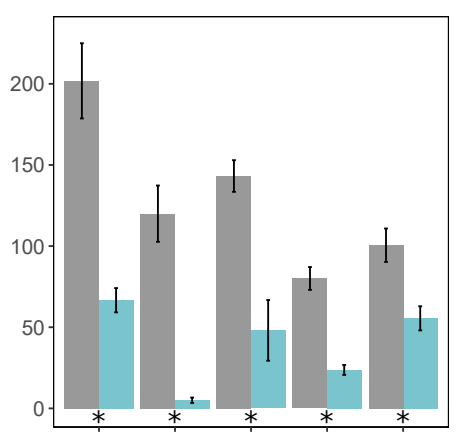

Agglutinated foraminifera
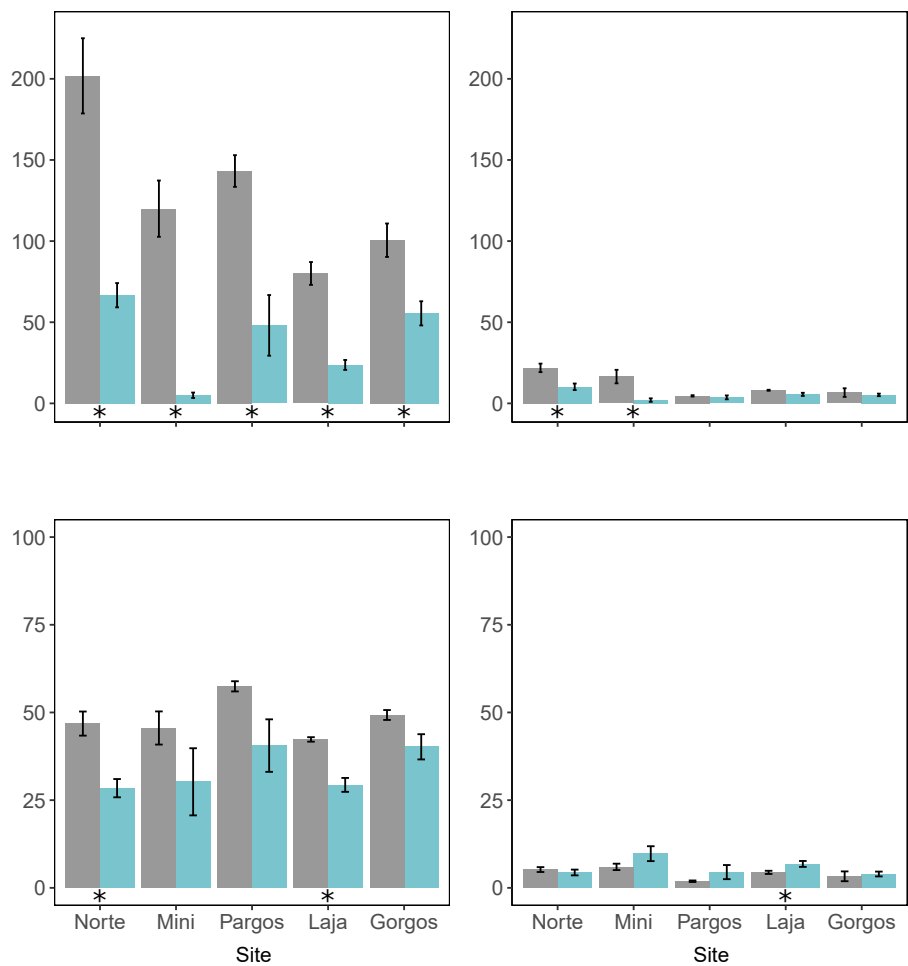

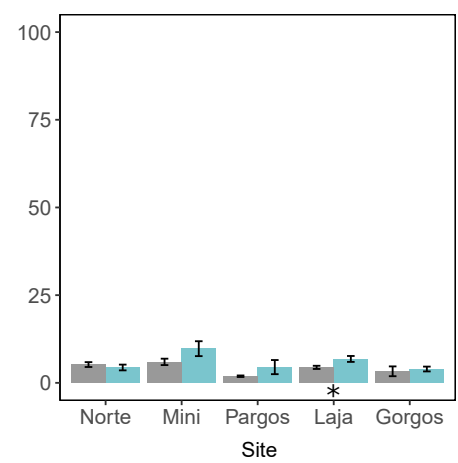

Figure 4. Absolute abundance (specimens per gram of sediment) and relative abundance (percentage) of different foraminifera test types (porcelaneous, hyaline, and agglutinated). Data are represented in mean $\pm \mathrm{SE}(n=5)$. The asterisk demarks a significant difference $(p<0.05)$ in abundance between paired springs and controls at each site, according to Mann-Whitney rank sum test.

The relative abundance of low-Mg foraminifera was lower at low $\Omega$ in Norte, Mini, and Laja (Norte: $W=25, p<0.01$; Mini: $W=25, p<0.01$; Pargos: $W=20, p=0.151$; Laja: $W=25, p<0.01$; Gorgos: $W=20, p=0.151)$. The relative abundance of intermediate- $\mathrm{Mg}$ foraminifera was significantly lower at low $\Omega$ in Norte and Pargos (Norte: $W=25, p<0.01$; Mini: $W=8, p=0.421$; Pargos: $W=$ 23, $p<0.05$; Laja: $W=18, p=0.309$; Gorgos: $W=20$, $p=0.151)$. In contrast, the relative abundance of high$\mathrm{Mg}$ foraminifera was higher at low $\Omega$ in Norte and Laja (Norte: $W=0, p<0.01$; Mini: $W=5, p=0.142$; Pargos: $W=5, p=0.151$; Laja: $W=0, p<0.01$; Gorgos: $W=5$, $p=0.151)$.

\subsection{Feeding strategy of calcareous foraminifera}

Calcareous foraminifera were divided into two groups based on their feeding strategy: heterotrophic-symbiont-barren foraminifera, and symbiont-bearing foraminifera. The absolute abundance of calcareous heterotrophic foraminifera was lower at low $\Omega$ than at high $\Omega$ at all sites but Gorgos (see Fig. 6 - Norte: $W=25, p<0.01$; Mini: $W=25, p<0.01$; Pargos: $W=25, p<0.05$; Laja: $W=25, p<0.01$; Gorgos: $W=20, p=0.151)$. The absolute abundance of symbiont- bearing foraminifera was also lower at low $\Omega$ than at high $\Omega$ at all sites but Gorgos (Norte: $W=24, p<0.05$; Mini: $W=25, p<0.01$; Pargos: $W=25, p<0.01$; Laja: $W=25$, $p<0.01$; Gorgos: $W=19, p=0.222$ ). The relative abundance of heterotrophic foraminifera was lower at low $\Omega$ than at high $\Omega$ in all sites but Gorgos (Norte: $W=25, p<0.01$; Mini: $W=25, p<0.01$; Pargos: $W=25, p<0.01$; Laja: $W=25, p<0.01$; Gorgos: $W=20, p=0.151)$. In contrast, the relative abundance of symbiont-bearing foraminifera was higher at low $\Omega$ at all sites but Gorgos (Norte: $W=0$, $p<0.01$; Mini: $W=0, p<0.01$; Pargos: $W=0, p<0.01$; Laja: $W=0, p<0.01$; Gorgos: $W=5, p=0.151)$.

\subsection{Symbiont type of calcareous foraminifera}

To test the differences among symbiont types on foraminifera abundance with respect to $\Omega$, symbiont-bearing foraminifera were divided into two groups: diatom-bearing foraminifera (Amphistegina and Asterigerina) and chlorophyte-bearing foraminifera (Archaias). The absolute abundance of diatombearing foraminifera was lower at low $\Omega$ at all sites (see Fig. 7 - Norte: $W=25, p<0.01$; Mini: $W=25, p<0.01$; Pargos: $W=25, p<0.01$; Laja: $W=25, p<0.01$; Gorgos: $W=23, p<0.05)$. The absolute abundance of chlorophyte- 

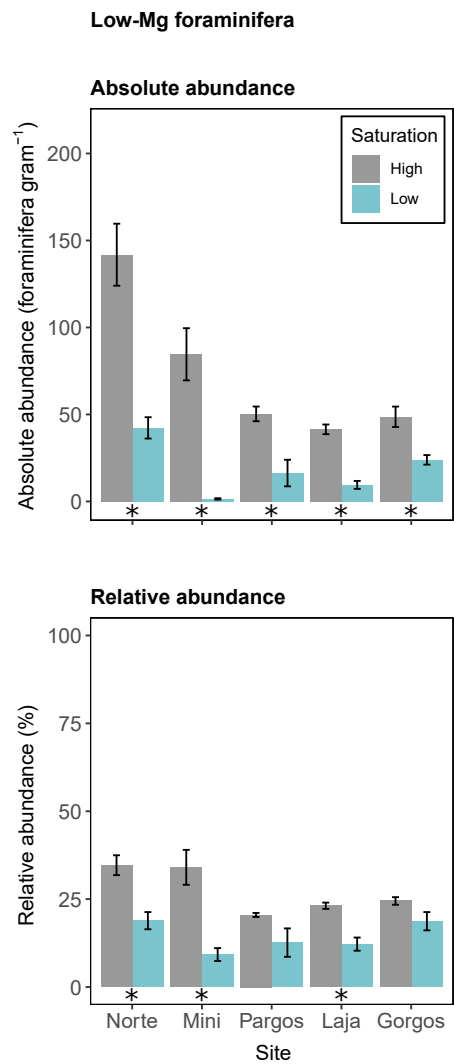

Intermediate-Mg foraminifera
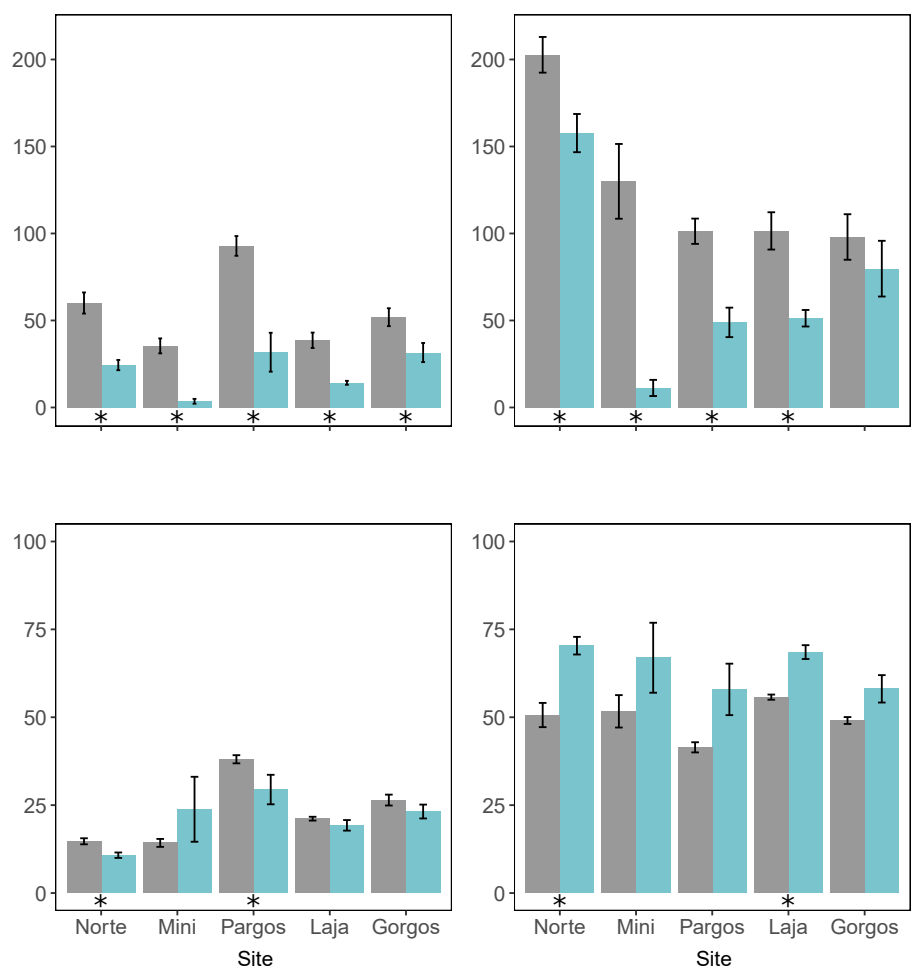

High-Mg foraminifera

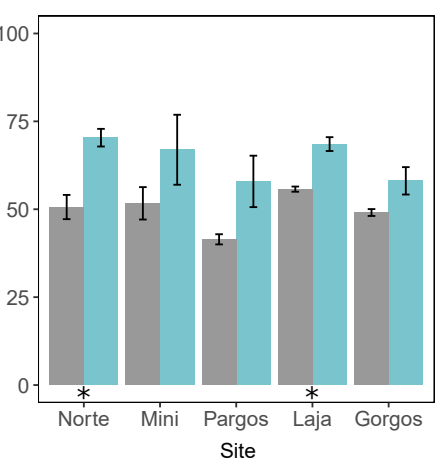

Figure 5. Absolute abundance (specimens per gram of sediment) and relative abundance (percentage) of foraminifera with different magnesium content tests. Data are represented in mean $\pm \operatorname{SE}(n=5)$. The asterisk demarks a significant difference $(p<0.05)$ in abundance between paired springs and controls at each site, according to Mann-Whitney rank sum test.

bearing foraminifera was lower at low $\Omega$ in Mini, Pargos, and Laja and did not vary significantly in Norte and Gorgos (Norte: $W=20, p=0.151$; Mini: $W=25, p<0.01$; Pargos: $W=24, p<0.05$; Laja: $W=25, p<0.01$; Gorgos: $W=12$, $p=0.1$ ).

The relative abundance of diatom-bearing foraminifera was lower at all sites but Mini (Norte: $W=25, p<0.01$; Mini: $W=17, \quad p=0.421$; Pargos: $W=24, \quad p<0.05$; Laja: $W=25, p<0.01$; Gorgos: $W=25, p<0.01$ ). Contrastingly, the relative abundance of chlorophyte-bearing foraminifera was higher at all sites but Mini (Norte: $W=0$, $p<0.01$; Mini: $W=8, p=0.421$; Pargos: $W=1, p<0.05$; Laja: $W=0, p<0.01$; Gorgos: $W=0, p<0.01)$.

\subsection{Environmental factors}

The nMDS plots showed a clear clustering of relative abundances between high and low $\Omega$, while this clustering was not apparent between sites at a specific saturation state (Fig. 8). The envfit function revealed that areas where calcareous heterotrophic foraminifera were relatively more abundant are the control sites, which are characterized by higher $\mathrm{pH}\left(R^{2}=0.3531, p=0.001\right)$, salinity $\left(R^{2}=0.4420, p=\right.$ 0.001 ), and $\Omega$ (represented as the arrow titled calcite in
Fig. $8, R^{2}=0.4735, p=0.001$ ), while the areas where calcareous heterotrophic foraminifera were less abundant are the spring sites, which are characterized by higher alkalinity (represented as arrow A in Fig. 8; $R^{2}=0.4420, p=0.001$ ) and higher total inorganic carbon (represented as arrow $\mathrm{C}$ in Fig. $\left.8 ; R^{2}=0.4261, p=0.001\right)$. Calcareous symbiontbearing foraminifera were relatively more abundant in low- $\Omega$ areas (blue symbols) with higher temperatures (represented as arrow T in Fig. $8 ; R^{2}=0.1234, p=0.036$ ), although the temperature is not on the main gradient of variation, and the difference among sites was at most $2{ }^{\circ} \mathrm{C}$, which is lower than diurnal or seasonal natural variability within sites. The relative abundance of agglutinated foraminifera was not affected by the main gradient explaining the maximal variance of data. These trends are consistent with field observations.

\section{9 $\quad$ Test weight}

The average test weights of Discorbis rosea (size fraction 250-355 $\mu \mathrm{m}$ ) did not differ among saturation states in any of the sites (Norte: $W=13, p=0.1$; Mini: $W=13, p=0.2$; Pargos: $W=7, p=0.309$; Laja: $W=8, p=0.421$; Gorgos: $W=20, p=0.151-$ see Fig. 9). 

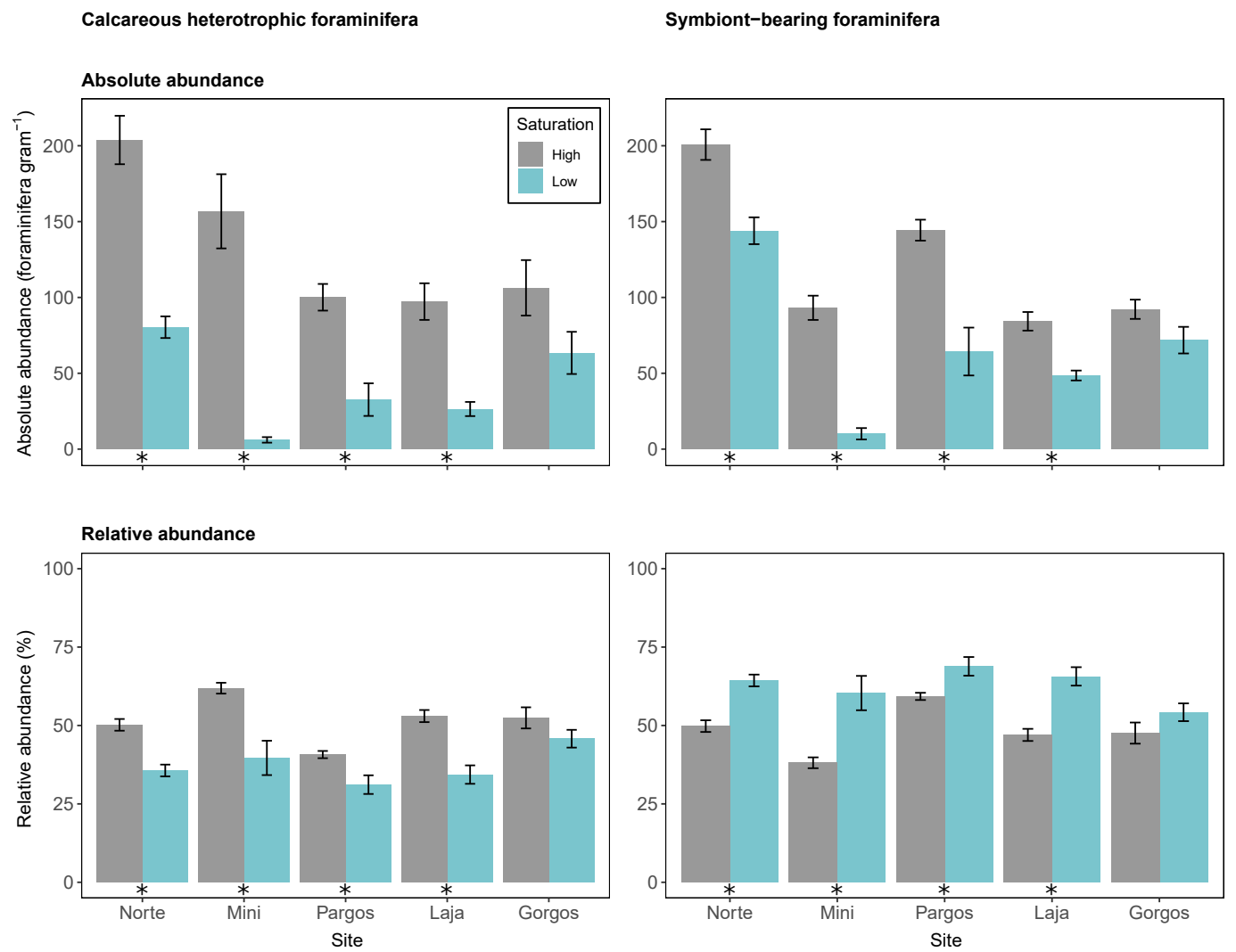

Figure 6. Absolute abundance (specimens per gram of sediment) and relative abundance (percentage) of different feeding strategies of calcareous foraminifera (symbiont-barren heterotrophic and symbiont-bearing). Data are represented in mean $\pm \mathrm{SE}(n=5)$. The asterisk demarks a significant difference $(p<0.05)$ in abundance between paired springs and controls at each site, according to Mann-Whitney rank sum test.

\section{Discussion}

\subsection{Absolute abundance of calcifying benthic foraminifera decreases at low- $\Omega$ springs}

The analysis of foraminiferal abundance in surface sediments collected from low- $\Omega$ submarine springs and control sites revealed that the absolute abundance of calcareous foraminifera was lower at springs than at control sites (Fig. 2). Calcification of calcareous foraminifera is a process that depends on the carbonate chemistry of seawater and requires calcite-supersaturated conditions at the calcification site (Erez, 2003; Bentov et al., 2009). Foraminifera endocytosis of seawater occurs to bring calcium and inorganic carbon to the active calcification site (Bentov et al., 2009). In the process, the vacuolated seawater is alkalinized to a $\mathrm{pH}$ of $\sim 9$ to overcome the magnesium-mediated inhibition of calcite precipitation and to promote the conversion of inorganic carbon from bicarbonate to carbonate ions (de Nooijer et al., 2009). This $\mathrm{pH}$ elevation at the site of calcification is achieved by using ATP to pump protons out of the foraminifera protoplasm (Glas et al., 2012b; Toyofuku et al., 2017). If the ambient $\mathrm{pH}$ is low, the foraminifera have to devote more energy to rising the intracellular $\mathrm{pH}$ to promote calcification, making the conditions at low-pH sites less favorable for calcification (de Nooijer et al., 2009). Indeed, this may explain the decrease we see in the total abundance of calcareous porcelaneous and hyaline foraminifera at the low- $\mathrm{pH}$, low- $\Omega$ submarine springs.

Agglutinated foraminifera absolute abundance was similar between springs and control sites in three of the five sampled sites, and their relative abundance was similar among springs and controls in four of the five sites (Fig. 4), although their abundance was overall low in both springs and control sites. Furthermore, SIMPER analysis revealed that agglutinated Gaudryina foraminifera relative abundance increased at low $\Omega$ in most of the sites (Fig. 3). Since agglutinated foraminifera tests are not made of calcium carbonate, they may be less influenced by the low- $\Omega$ seawater at the springs than calcareous foraminifera. A lesser impact of low $\mathrm{pH}$ on agglutinated foraminifera abundance has also been observed in foraminifera present at $\mathrm{CO}_{2}$ vents in Papua New Guinea (Uthicke et al., 2013) and Ischia, in the Mediterranean Sea (Dias et al., 2010). Similarly, the abundance of non-calcifying thecate and agglutinated foraminifera living 


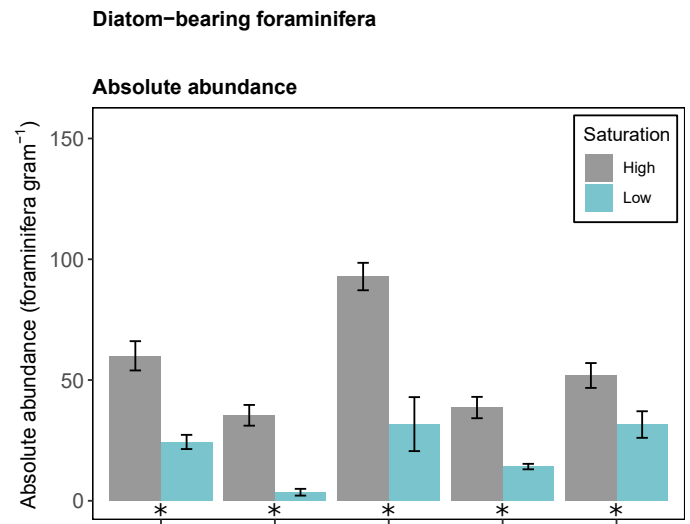

Chlorophyte-bearing foraminifera
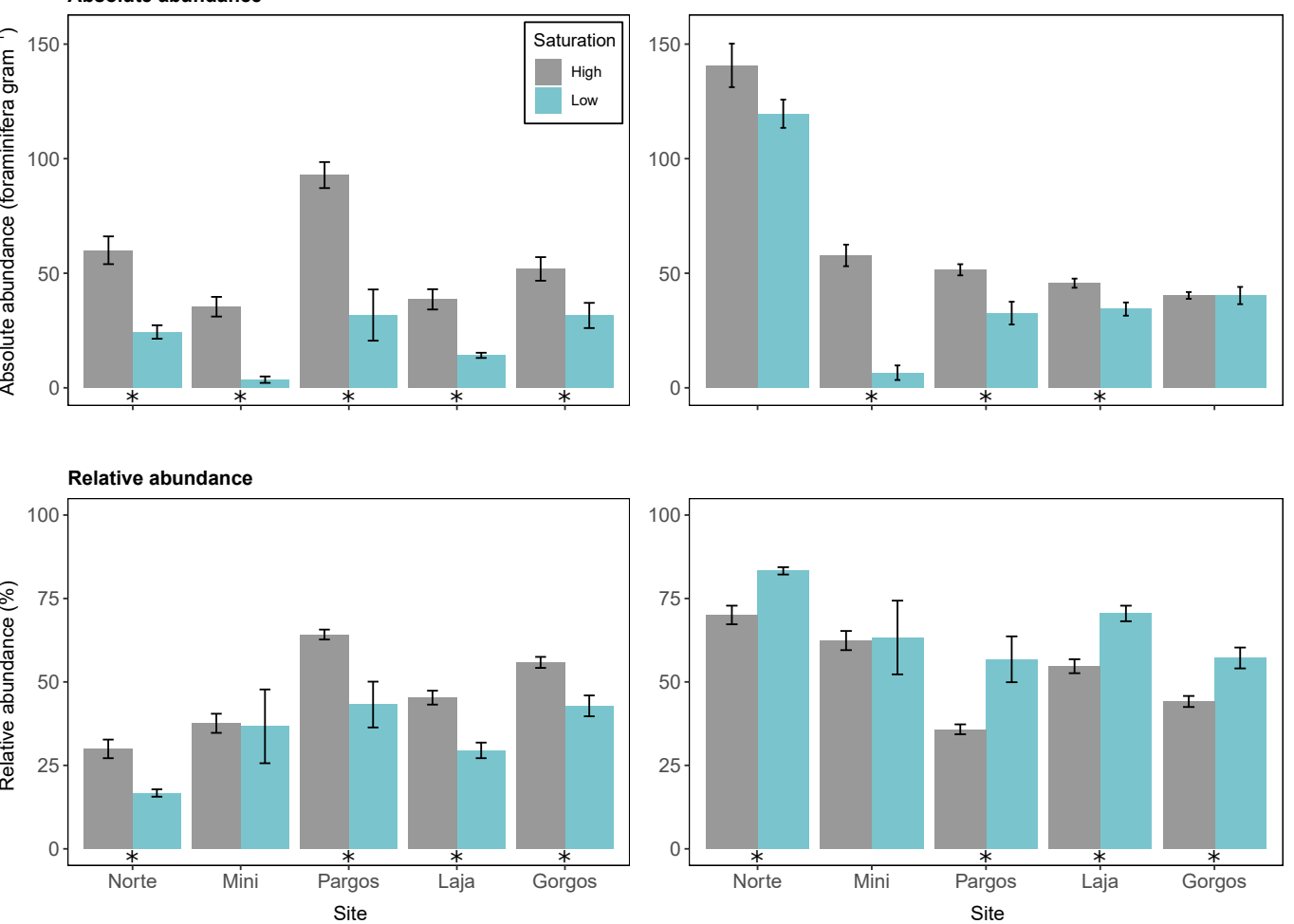

Figure 7. Absolute abundance (specimens per gram of sediment) and relative abundance (percentage) of large calcareous foraminifera that host different symbionts (diatoms and chlorophytes). Data are represented in mean $\pm \mathrm{SE}(n=5)$. The asterisk demarks a significant difference $(p<0.05)$ in abundance between paired springs and controls at each site, according to Mann-Whitney rank sum test.

in direct contact with experimentally injected $\mathrm{CO}_{2}$ hydrate did not decline significantly with decreasing $\mathrm{pH}$ (Bernhard et al., 2009). However, species-specific survival rates of agglutinated foraminifera during a laboratory experiment at 2000 ppm of $p \mathrm{CO}_{2}$ suggest that other agglutinated species different than Gaudryina may respond in a different manner to low $\Omega$ (van Dijk et al., 2017).

Since many environmental parameters covary in natural environments (Andersson et al., 2015), including at our field site, it is possible that the trends in absolute and relative abundances of foraminifera present at the springs are due to species-specific salinity preferences (the only other variable that consistently different between springs and control sites). The salinity of the discharging water at the sampled springs is $>30$ for $93 \%$ of the time, and it is constantly higher than 27 (Crook et al., 2013), as previously mentioned. Although the salinity tolerance ranges are not known for all the species found in the study area, many foraminifera that are abundant in shallow warm coastal waters, such as those at our sites, have a very high salinity tolerance (Brasier, 1980). Quinqueloculina spp. has been found at salinity ranges of 12-35 with abundance peaks at 17 and 35 (Horton and Murray, 2007), Amphistegina lessonii has been kept at salini- ties between 25 and 45 in a lab experiment (Geerken et al., 2018), and Archaias has been reported to be present at salinities of 29-39 (Hallock and Peebles, 1993). Moreover, adaptation to changes in salinity requires increased cellular osmoregulation (McLusky et al., 2004), which is expected to affect both agglutinated and calcareous foraminifera abundance. Since agglutinated foraminifera abundance is similar at the springs and control sites (Fig. 4) and does not seem to be affected by the main gradient of variation in carbonate chemistry and salinity (Fig. 8), we suggest that $\Omega$ and $\mathrm{pH}$ are the main drivers of calcareous foraminifera abundances seen in this study. Consistent with this conclusion, the trends we see in the absolute and relative abundance of calcareous and agglutinated foraminifera are in line with observations from other field studies where salinities did not differ between low- and ambient-pH sampling locations (Fabricius et al., 2011; Uthicke et al., 2013). Hence, the lower abundance of calcareous foraminifera we and others have observed in diverse settings with low $\Omega$ suggests that a future reduction in $\Omega$ will negatively affect calcareous benthic foraminifera. 


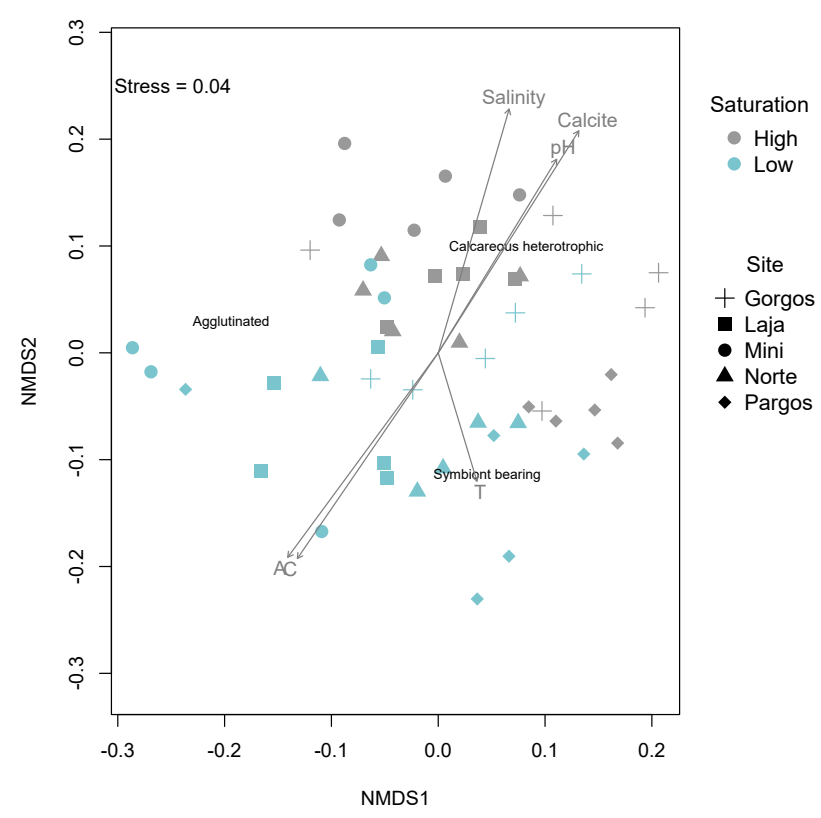

Figure 8. Non-metric multidimensional scaling (nMDS) ordination plot for community structure (relative abundance) by carbonate saturation state and site, with overlaid environmental parameters ( $A=$ total alkalinity; $\mathrm{C}=$ total inorganic carbon; $T=$ temperature).

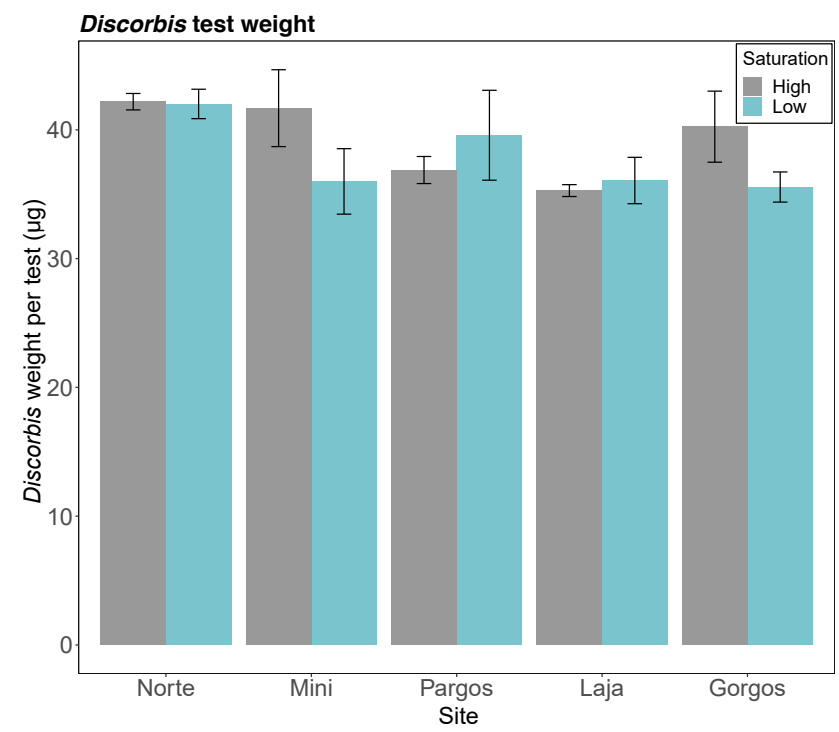

Figure 9. Mean weight of Discorbis rosea tests (size fraction 250$355 \mu \mathrm{m})$ at low and high saturation at different submarine spring sites. Data are represented in mean $\pm \mathrm{SE}$.

\subsection{Relative abundance of foraminifera with porcelaneous, high-magnesium tests increases in low- $\Omega$ springs}

While the absolute abundance of both porcelaneous and hyaline foraminifera was lower at low $\Omega$, a trend towards higher relative abundance of porcelaneous foraminifera and lower relative abundance of hyaline foraminifera is observed (Fig. 4). The higher relative abundance of porcelaneous (Fig. 4) and high-magnesium foraminifera (Fig. 5) is driven by Archaias angulatus, which is the most common species found and contributes the most to community dissimilarity in all the sites (Fig. 3). Archaias angulatus is well preserved in sediments due to its robust, thick test (Hallock and Peebles, 1993), strengthened by crystal pillars (Martin, 1986), and it has been reported to account for more than $20 \%$ of the foraminiferal population in the southern Florida shelf (Knorr et al., 2015) and up to $54 \%$ of dead assemblages from the northern Florida Keys (Martin, 1986) and is the most common species in Banco Chinchorro in the southern Yucatán Peninsula (Gischler and Möder, 2009). The lower relative abundance of hyaline, low-magnesium foraminifera at low $\Omega$ (Figs. 4 and 5) is attributed to the decrease of Discorbis and Asterigerina (Fig. 3). These results are in contrast with the idea that porcelaneous, high-magnesium foraminifera would be the "first responders" (Fujita et al., 2011) to ocean acidification. This was suggested because high-Mg calcite is more soluble than low-Mg calcite and aragonite at a given $p \mathrm{CO}_{2}$ (Morse et al., 2006), and because $\mathrm{Mg}$ inhibits calcite crystallization. This inconsistency can be attributed to the lower solubility of the robust tests.

The calcification pathway of perforate hyaline foraminifera (reviewed by de Nooijer et al., 2014) has been studied in more detail than the calcification process of porcelaneous foraminifera. Hyaline foraminifera capture ions through seawater endocytosis (Bentov et al., 2009; de Nooijer et al., 2009) and transmembrane transport (Nehrke et al., 2013) and store them in separated intracellular reservoirs of inorganic carbon and calcium (Ter Kuile and Erez, 1991; Toyofuku et al., 2008). A perforated test is then secreted extracellularly within a primary organic sheet after intracellular $\mathrm{Mg}$ discrimination and a $\mathrm{pH}$ increase in the vacuolated seawater to a $\mathrm{pH}$ of $\geq 9$ (Zeebe and Sanyal, 2002; Erez, 2003; de Nooijer et al., 2009). In contrast, porcelaneous foraminifera precipitate calcite needles inside intracellular vesicles (at a $\mathrm{pH}$ of $\sim 9$ ) that are later transported and randomly assembled in an extracellular organic matrix to form a new test chamber (Angell, 1980; Hemleben et al., 1986; Erez, 2003; de Nooijer et al., 2009). These transporting vesicles have been reported to have a $\mathrm{pH}$ of 7.5-8.0 (de Nooijer et al., 2009). Since these vesicles have a lower $\mathrm{pH}$, it is possible that fewer protons are pumped out of the vesicle. In addition, the lack of internal calcium and inorganic carbon pools may require less energy to precipitate calcite tests, which can be a competitive advantage that explains the increase in relative abundance of porcelaneous foraminifera we see at low- $\mathrm{pH}$, low- $\Omega$ springs. Another explanation, noted above, could be that the lower dissolution rates of the more robust porcelaneous tests (Brasier, 1980; Schmiedl et al., 1997) result in the observed increase in the abundance of these tests. However, further research is needed to test these hypotheses and to better understand 
the calcification pathway and preservation of porcelaneous foraminifera. These results can guide controlled experiments in a laboratory setting.

\subsection{Symbiont-bearing foraminifera increase in relative abundance at low- $\Omega$ springs}

The relative abundance of heterotrophic foraminifera decreased, while the relative abundance of symbiont-bearing foraminifera increased, in most of the springs (Fig. 6). Foraminifera that host photosynthetic symbionts may be more resilient to low $\Omega$, since they can access additional energy derived from photosynthates translocated from the algae (Hallock, 2000) to increase $\mathrm{pH}$ at the calcification site and for alkalinization of seawater vacuoles. In addition, symbiotic algae can promote calcification by removing foraminiferal metabolic $\mathrm{N}$ and $\mathrm{P}$, which impede crystal formation, by providing organic matter used to synthesize the organic matrix that precedes test growth (Fujita et al., 2011) and by increasing the $\mathrm{pH}$ on the surface of foraminifera (Glas et al., 2012a). These mechanisms may explain the significant increase in the relative abundance of symbiont-bearing foraminifera $(>50 \%$ of the total calcareous population), while the relative abundance of calcareous heterotrophic foraminifera decreased $(<50 \%)$ at low- $\Omega$ springs. Although symbiont-bearing calcareous foraminifera were relatively more abundant than symbiont-barren foraminifera at low- $\Omega$ sites, their absolute abundance decreased in comparison with sites at ambient $\Omega$, indicating that, despite the symbionts, the conditions were less favorable than at ambient conditions. Short laboratory experiments with symbiont-bearing foraminifera cultured at high $p \mathrm{CO}_{2}$ have reported reduced net calcification (Fujita et al., 2011; Hikami et al., 2011) and tests dissolution signs (McIntyre-Wressnig et al., 2013). While photosynthetic activity may promote calcification, it did not fully compensate for the deleterious effects of elevated $p \mathrm{CO}_{2}$ on foraminifera calcification incubated in laboratory (Glas et al., 2012a) and field experiments (Uthicke and Fabricius, 2012). These studies suggest that benthic symbiont-bearing foraminifera can better survive at high $p \mathrm{CO}_{2}$, but their calcification is reduced.

Foraminifera that host chlorophytes (Archaias) were relatively more abundant at springs than those that host diatoms (Amphistegina and Asterigerina; Fig. 7). Hyaline foraminifera that host diatoms were thought to be more resilient to high $p \mathrm{CO}_{2}$ than other symbiont-bearing foraminifers based on a meta-analysis of studies assessing the impacts of acidification on large benthic foraminifera (Doo et al., 2014). However, none of the studies included in the meta-analyses focused on chlorophyte-bearing foraminifera, and due to the high variability in methodology, duration, and species used in the experiments, it is not possible to make a direct comparison between these studies and an assemblage found at the natural low- $\Omega$ springs in our study. Foraminifera that host chlorophytes may be more resilient to ocean acidification than those that host di- atoms, or the robustness of Archaias tests may be responsible for this difference in relative abundance. It is also plausible that the size of the symbiont-bearing foraminifera influences the survival and preservation under low- $\Omega$ conditions. The relative abundance of Asterigerina decreased at low $\Omega$ while Amphistegina increased, in spite of both being hyaline foraminifera that host diatoms (Fig. 3). The larger size of Amphistegina in comparison to Asterigerina may allow for hosting a larger concentration of photosynthetic algae, as it has been suggested that the number of symbionts increases with test size (Hönisch and Hemming, 2004). In fact, Archaias has the largest tests of all the species found at the springs in this study. Furthermore, a larger size has been linked to reduced dissolution due to a smaller surface-to-volume ratio (Hönisch and Hemming, 2004), which may explain why large foraminifera are more abundant overall than smaller foraminifera at this location.

\subsection{Discorbis rosea weight did not significantly vary among springs and control sites}

The test weight of $D$. rosea did not significantly vary among springs and control sites. This lack of difference may be due to the large variability in test weight within populations and individuals. The variability in tests weights within a species may be due to differential individual growth rates (Fujita et al., 2011), body sizes (Henehan et al., 2017), or genotypes (Davis et al., 2017) and diverse calcification performance under the same $\Omega$ conditions. In our study, the weighted tests were all counted from the $250-355 \mu \mathrm{m}$ sediment fraction, and we took special care in selecting individuals of very similar size. However, each test was not normalized to shell diameter; hence the wide variability in test weights may be partially related to the range in test sizes.

\subsection{Implications}

The reduced absolute abundance of benthic foraminifera at low- $\Omega$ springs suggest that there may be an overall decrease in benthic foraminifera abundance as a consequence of ocean acidification, with subsequent repercussions on the global carbon cycle and marine food web. Archaias angulatus, the most common species found in this study, is known to represent a large proportion of the foraminiferal population in different parts of the western tropical Atlantic Ocean (Martin, 1986; Gischler and Möder, 2009; Knorr et al., 2015), being the dominant large benthic foraminifera in the FloridaBahamas carbonate province (Hallock et al., 1986). A laboratory study with $A$. angulatus reported a $50 \%$ decrease in growth rate after 28 days at $\mathrm{pH} 7.6$ and an estimated reduction of $85 \%$ in carbonate production by this species in the southern Florida Reef Tract and Florida Bay, from 0.27 to $0.04 \mathrm{Mt} \mathrm{yr}^{-1}$ (Knorr et al., 2015). Besides changes in carbonate production, a decrease in foraminiferal abundance may have cascade effects on the ecosystem, since foraminifera 
are an important link in the marine food web, as they prey on bacteria and algae and are predated on by many animals such as gastropods, bivalves, echinoderms, and crustaceans (Culver and Lipps, 2003).

\section{Conclusion}

The absolute abundance of all large calcareous foraminifera decreased at springs discharging low- $\Omega$, low-pH water. Porcelaneous, high-magnesium foraminifera were relatively less impacted compared to hyaline foraminifera at the springs, possibly due to their different calcification mechanism, more robust tests, and the lack of internal carbon and calcium pools. The relative abundance of symbiont-bearing foraminifera increased while heterotrophic symbiont-barren foraminifera decreased under low $\Omega$ conditions, which may be explained by the higher energy availability provided by the symbiont to elevate the $\mathrm{pH}$ at the site of calcification. Chlorophyte-bearing foraminifera were relatively more abundant than diatom-bearing foraminifera. These trends are driven by the abundant large Archaias angulatus, porcelaneous foraminifera that host chlorophytes, which may be more resilient to low $\Omega$ due to their test's robustness and large size that can lead to a higher concentration of symbiotic algae and reduced test dissolution. Further laboratory experiments are needed to confirm these results in a controlled setting without covarying environmental variables and to better understand the calcification pathway of porcelaneous foraminifera.

Data availability. Data are available from the BCO-DMO repository https://www.bco-dmo.org/project/488852 (last access: 12 November 2018) (BCO-DMO, 2018).

Author contributions. AM and AP conceived and designed the experiments. AM, AP, MRV, and LHT conducted the field work. AM and AP analyzed the data. AM, AP, LHT and MRV contributed reagents, materials, and analysis tools. AM and AP primarily wrote the paper, and LHT and MRV provided critical edits.

Competing interests. The authors declare that they have no conflict of interest.

Acknowledgements. We are grateful to Daniel Mendoza, Patricia Domínguez, Caitlin Celic, Grace Moreno, and Rob Franks for assistance during laboratory analysis and Yui Takeshita for assistance during field work. We would like to thank Joan Bernhard for insightful comments on this project and Ellen Thomas and Daniela Schmidt for advice regarding foraminifera identification and biology. The comments and suggestions of Inge van Dijk and two anonymous reviewers significantly improved this paper. This research was funded by the National Science Foundation-1040952 (to Adina Paytan) and by the Ministry of Education of Spain's Argo Global Grant and the Myers Oceanographic and Marine Biology Trust Grant (to Ana Martinez). The funders had no role in the study design, data collection and analysis, decision to publish, or preparation of the paper.

Edited by: Jack Middelburg

Reviewed by: Inge van Dijk and two anonymous referees

\section{References}

Andersson, A. J., Kline, D. I., Edmunds, P. J., Archer, S. D., Bednaršek, N., Carpenter, R. C., Chadsey, M., Goldstein, P., Grottoli, A. G., Hurst, T. P., King, A. L., Kubler, J. E., Kuffner, I. B., Mackey, K. R. M., Menge B. A., Paytan, A., Riebesell, U., Schnetzer, A., Warner, M. E., and Zimmerman, R. C.: Understanding ocean acidification impacts on organismal to ecological scales, Oceanography, 28, 16-27, https://doi.org/10.5670/oceanog.2015.27, 2015.

Angell, R. W.: Test morphogenesis (chamber formation) in the foraminifer Spiroloculina hyalina Schulze, J. Foramin. Res., 10, 89-101, 1980.

Back, W., Hanshaw, B. B., Pyle, T. E., Plummer, L. N., and Weidie, A.: Geochemical significance of groundwater discharge and carbonate solution to the formation of Caleta Xel Ha, Quintana Roo, Mexico, Water Resour. Res., 15, 1521-1535, 1979.

BCO-DMO: Project: Calcification in low saturation seawater: What can we learn from organisms in the proximity of low $\mathrm{pH}$; undersaturated submarine springs, available at: https://www.bco-dmo. org/project/488852, last access: 12 November 2018.

Bentov, S., Brownlee, C., and Erez, J.: The role of seawater endocytosis in the biomineralization process in calcareous foraminifera, P. Natl. Acad. Sci. USA, 106, 21500-21504, https://doi.org/10.1073/pnas.0906636106, 2009.

Bernhard, J. M., Barry, J. P., Buck, K. R., and Starczak, V. R.: Impact of intentionally injected carbon dioxide hydrate on deep-sea benthic foraminiferal survival, Glob. Change Biol., 15, 20782088, 2009.

Brasier, M. D.: Microfossils, G. Allen \& Unwin, London, UK, 1980.

Caldeira, K. and Wickett, M. E.: Oceanography: anthropogenic carbon and ocean pH, Nature, 425, p. 365, 2003.

Crevison, H. and Hallock, P.: Foraminifera as Bioindicators: Key Subtropical Western Atlantic and Caribbean Taxa, University of South Florida, St. Petersburg, FL, USA, available at: https://www.marine.usf.edu/reefslab/foramcd/html_files/ titlepage.htm (last access: 4 June 2014), 2001.

Crook, E., Potts, D., Rebolledo-Vieyra, M., Hernandez, L., and Paytan, A.: Calcifying coral abundance near low-pH springs: implications for future ocean acidification, Coral Reefs, 31, 239-245, 2012.

Crook, E. D., Cohen, A. L., Rebolledo-Vieyra, M., Hernandez, L., and Paytan, A.: Reduced calcification and lack of acclimatization by coral colonies growing in areas of persistent natural acidification, P. Natl. Acad. Sci. USA, 110, 11044-11049, 2013.

Crook, E. D., Kroeker, K. J., Potts, D. C., Rebolledo-Vieyra, M., Hernandez-Terrones, L. M., and Paytan, A.: Recruitment and succession in a tropical benthic community in re- 
sponse to in-situ ocean acidification, Plos One, 11, e0146707, https://doi.org/10.1371/journal.pone.0146707, 2016.

Culver, S. J. and Lipps, J. H.: Predation on and by Foraminifera, in: Predator - Prey Interactions in the Fossil Record, Springer, Boston, MA, USA, 7-32, 2003.

Davis, C. V., Rivest, E. B., Hill, T. M., Gaylord, B., Russell, A. D., and Sanford, E.: Ocean acidification compromises a planktic calcifier with implications for global carbon cycling, Sci. Rep.-UK, 7, 2225, https://doi.org/10.1038/s41598-017-01530-9, 2017.

de Nooijer, L. J., Toyofuku, T., and Kitazato, H.: Foraminifera promote calcification by elevating their intracellular pH, P. Natl. Acad. Sci. USA, 106, 15374-15378, https://doi.org/10.1073/pnas.0904306106, 2009.

de Nooijer, L. J., Spero, H., Erez, J., Bijma, J., and Reichart, G.J.: Biomineralization in perforate foraminifera, Earth-Sci. Rev., 135, 48-58, 2014.

Dias, B., Hart, M., Smart, C., and Hall-Spencer, J.: Modern seawater acidification: the response of foraminifera to high- $\mathrm{CO}_{2}$ conditions in the Mediterranean Sea, J. Geol. Soc. London, 167, 843846,2010

Dickson, A. G., Sabine, C. L., and Christian, J. R.: Guide to best practices for ocean $\mathrm{CO}_{2}$ measurements, North Pacific Marine Science Organization, Sidney, BC, Canada, 2007.

Dixon, P.: VEGAN, a package of R functions for community ecology, J. Veg. Sci., 14, 927-930, 2003.

Doo, S. S., Fujita, K., Byrne, M., and Uthicke, S.: Fate of calcifying tropical symbiont-bearing large benthic foraminifera: living sands in a changing ocean, Biol. Bull., 226, 169-186, 2014.

d'Orbigny, A.: Foraminifères, A. Bertrand, Paris, France, 1839.

Erez, J.: The source of ions for biomineralization in foraminifera and their implications for paleoceanographic proxies, Rev. Mineral. Geochem., 54, 115-149, 2003.

Fabricius, K. E., Langdon, C., Uthicke, S., Humphrey, C., Noonan, S., De'ath, G., Okazaki, R., Muehllehner, N., Glas, M. S., and Lough, J. M.: Losers and winners in coral reefs acclimatized to elevated carbon dioxide concentrations, Nat. Clim. Change, 1, 165-169, 2011.

Fabry, V. J., Seibel, B. A., Feely, R. A., and Orr, J. C.: Impacts of ocean acidification on marine fauna and ecosystem processes, ICES J. Mar. Sci., 65, 414-432, 2008.

Fujita, K., Hikami, M., Suzuki, A., Kuroyanagi, A., Sakai, K., Kawahata, H., and Nojiri, Y.: Effects of ocean acidification on calcification of symbiont-bearing reef foraminifers, Biogeosciences, 8, 2089-2098, https://doi.org/10.5194/bg-8-20892011, 2011.

Geerken, E., de Nooijer, L. J., van Dijk, I., and Reichart, G.J.: Impact of salinity on element incorporation in two benthic foraminiferal species with contrasting magnesium contents, Biogeosciences, 15, 2205-2218, https://doi.org/10.5194/bg-152205-2018, 2018.

Gischler, E. and Möder, A.: Modern benthic foraminifera on Banco Chinchorro, Quintana Roo, Mexico, Facies, 55, 27-35, 2009.

Glas, M. S., Fabricius, K. E., de Beer, D., and Uthicke, S.: The $\mathrm{O}_{2}$, $\mathrm{pH}$ and $\mathrm{Ca}_{2}+$ microenvironment of benthic foraminifera in a high $\mathrm{CO}_{2}$ world, PloS One, 7, e50010, 2012a.

Glas, M. S., Langer, G., and Keul, N.: Calcification acidifies the microenvironment of a benthic foraminifer (Ammonia sp.), J. Exp. Mar. Biol. Ecol., 424, 53-58, 2012b.
Hain, M., Sigman, D., and Haug, G.: 8.18 - The biological Pump in the Past, Reference Module in Earth Systems and Environmental Sciences, Treatise on Geochemistry (Second Edition), The Oceans and Marine Geochemistry, 8, 485-517, 2014.

Hallock, P.: Why are larger foraminifera large?, Paleobiology, 11, 195-208, 1985.

Hallock, P.: Symbiont-bearing foraminifera: harbingers of global change?, Micropaleontology, 46, 95-104, 2000.

Hallock, P. and Glenn, E. C.: Larger foraminifera: a tool for paleoenvironmental analysis of Cenozoic carbonate depositional facies, Palaios, 55-64, 1986.

Hallock, P. and Peebles, M. W.: Foraminifera with chlorophyte endosymbionts: habitats of six species in the Florida Keys, Mar. Micropaleontol., 20, 277-292, 1993.

Hallock, P., Cottey, T. L., Forward, L. B., and Halas, J.: Population biology and sediment production of Archaias angulatus (Foraminiferida) in Largo Sound, Florida, J. Foramin. Res., 16, $1-8,1986$.

Haynert, K., Schönfeld, J., Riebesell, U., and Polovodova, I.: Biometry and dissolution features of the benthic foraminifer Ammonia aomoriensis at high $p \mathrm{CO}_{2}$, Mar. Ecol. Prog. Ser., 432, 53-67, 2011.

Hemleben, C., Erson, O., Berthold, W., and Spindler, M.: Calcification and chamber formation in Foraminifera-a brief overview, Biomineralization in lower plants and animals, edited by: Leadbeater, B. S. C. and Riding, R., Clarendon Press, Oxford, UK, 237-249. 1986.

Henehan, M. J., Evans, D., Shankle, M., Burke, J. E., Foster, G. L., Anagnostou, E., Chalk, T. B., Stewart, J. A., Alt, C. H. S., Durrant, J., and Hull, P. M.: Size-dependent response of foraminiferal calcification to seawater carbonate chemistry, Biogeosciences, 14, 3287-3308, https://doi.org/10.5194/bg-14-3287-2017, 2017.

Hikami, M., Ushie, H., Irie, T., Fujita, K., Kuroyanagi, A., Sakai, K., Nojiri, Y., Suzuki, A., and Kawahata, H.: Contrasting calcification responses to ocean acidification between two reef foraminifers harboring different algal symbionts, Geophys. Res. Lett., 38, L19601, https://doi.org/10.1029/2011GL048501, 2011.

Hofmann, G. E., Smith, J. E., Johnson, K. S., Send, U., Levin, L. A., Micheli, F., Paytan, A., Price, N. N., Peterson, B., and Takeshita, Y.: High-frequency dynamics of ocean pH: a multi-ecosystem comparison, PloS One, 6, e28983, https://doi.org/10.1371/journal.pone.0028983, 2011.

Hönisch, B. and Hemming, N. G.: Ground-truthing the boron isotope-paleo-pH proxy in planktonic foraminifera shells: Partial dissolution and shell size effects, Paleoceanography, 19, PA4010, https://doi.org/10.1029/2004PA001026, 2004.

Horton, B. P. and Murray, J. W.: The roles of elevation and salinity as primary controls on living foraminiferal distributions: Cowpen Marsh, Tees Estuary, UK, Mar. Micropaleontol., 63, 169-186, 2007.

Keul, N., Langer, G., de Nooijer, L. J., and Bijma, J.: Effect of ocean acidification on the benthic foraminifera Ammonia sp. is caused by a decrease in carbonate ion concentration, Biogeosciences, 10, 6185-6198, https://doi.org/10.5194/bg-10-6185-2013, 2013.

Knorr, P. O., Robbins, L. L., Harries, P. J., Hallock, P., and Wynn, J.: Response of the miliolid Archaias angulatus to simulated ocean acidification, J. Foramin. Res., 45, 109-127, 2015. 
Legendre, L. and Le Fèvre, J.: Microbial food webs and the export of biogenic carbon in oceans, Aquat. Microb. Ecol., 9, 69-77, 1995.

Lueker, T. J., Dickson, A. G., and Keeling, C. D.: Ocean $p \mathrm{CO}_{2}$ calculated from dissolved inorganic carbon, alkalinity, and equations for $\mathrm{K} 1$ and $\mathrm{K} 2$ : validation based on laboratory measurements of $\mathrm{CO}_{2}$ in gas and seawater at equilibrium, Mar. Chem., 70, 105-119, 2000.

Martin, R. E.: Habitat and distribution of the foraminifer Archaias angulatus (Fichtel and Moll)(Miliolina, Soritidae), northern Florida Keys, J. Foramin. Res., 16, 201-206, 1986.

McIntyre-Wressnig, A., Bernhard, J. M., McCorkle, D. C., and Hallock, P.: Non-lethal effects of ocean acidification on the symbiont-bearing benthic foraminifer Amphistegina gibbosa, Mar. Ecol. Prog. Ser., 472, 45-60, 2013.

McLusky, D. S., Elliott, M., and Elliott, M.: The estuarine ecosystem: ecology, threats and management, Oxford University Press on Demand, Oxford, UK, 2004.

Morse, J. W., Andersson, A. J., and Mackenzie, F. T.: Initial responses of carbonate-rich shelf sediments to rising atmospheric $p \mathrm{CO}_{2}$ and "ocean acidification": Role of high $\mathrm{Mg}$-calcites, Geochim. Cosmochim. Ac., 70, 5814-5830, 2006.

Muller, P. H.: Sediment production and population biology of the benthic foraminifer Amphistegina madagascariensis 1, 2, Limnol. Oceanogr., 19, 802-809, 1974.

Murray, J. W.: Ecology and distribution of benthic foraminifera, Biology of Foraminifera, in: Biology of the Foraminifera, edited by: Lee, J. J. and Anderson, O. R., Academic, London, UK, 221253, 1991

Nehrke, G., Keul, N., Langer, G., de Nooijer, L. J., Bijma, J., and Meibom, A.: A new model for biomineralization and traceelement signatures of Foraminifera tests, Biogeosciences, 10, 6759-6767, https://doi.org/10.5194/bg-10-6759-2013, 2013.

Null, K. A., Knee, K. L., Crook, E. D., de Sieyes, N. R., RebolledoVieyra, M., Hernández-Terrones, L., and Paytan, A.: Composition and fluxes of submarine groundwater along the Caribbean coast of the Yucatan Peninsula, Cont. Shelf Res., 77, 38-50, 2014.

Oksanen, J., Blanchet, F. G., Kindt, R., Legendre, P., Minchin, P. R., O'hara, R., Simpson, G. L., Solymos, P., Stevens, M. H. H., and Wagner, H.: Package "vegan", Community ecology package, version, 2, availabe at: https://cran.r-project.org/web/packages/ vegan/vegan.pdf (last access: 12 November 2018), 2013.

Orr, J. C., Fabry, V. J., Aumont, O., Bopp, L., Doney, S. C., Feely, R. A., Gnanadesikan, A., Gruber, N., Ishida, A., Joos, F., Key, R. M., Lindsay, K., Maier-Reimer, E., Matear, R., Monfray, P., Mouchet, A., Najjar, R. G., Plattner, G. K., Rodgers, K. B., Sabine, C. L., Sarmiento, J. L., Schlitzer, R., Slater, R. D., Totterdell, I. J., Weirig, M. F., Yamanaka, Y., and Yool, A.: Anthropogenic ocean acidification over the twenty-first century and its impact on calcifying organisms, Nature, 437, 681-686, https://doi.org/10.1038/nature04095, 2005.

Paytan, A., Crook, E. D., Cohen, A. L., Martz, T. R., Takashita, Y., Rebolledo-Vieyra, M., and Hernandez, L.: Reply to IglesiasPrieto et al.: Combined field and laboratory approaches for the study of coral calcification, P. Natl. Acad. Sci. USA, 111, E302E303, 2014.

Pettit, L. R., Hart, M. B., Medina-Sanchez, A. N., Smart, C. W., Rodolfo-Metalpa, R., Hall-Spencer, J. M., and
Prol-Ledesma, R. M.: Benthic foraminifera show some resilience to ocean acidification in the northern Gulf of California, Mexico, Mar. Pollut. Bull., 73, 452-462, https://doi.org/10.1016/j.marpolbul.2013.02.011, 2013.

Pierrot, D., Lewis, E., and Wallace, D.: MS Excel program developed for CO2 system calculations, ORNL/CDIAC-105a, Carbon Dioxide Information Analysis Center, Oak Ridge National Laboratory, US Department of Energy, Oak Ridge, Tennessee, USA, 2006.

Poag, C. W.: Ecologic atlas of benthic foraminifera of the Gulf of Mexico, Marine Science International, Woods Hole, MA, USA, 1981.

Raven, J., Caldeira, K., Elderfield, H., Hoegh-Guldberg, O., Liss, P., Riebesell, U., Shepherd, J., Turley, C., and Watson, A.: Ocean acidification due to increasing atmospheric carbon dioxide, Policy document 12/05, Royal Society, London, UK, 2005.

Sabine, C. L., Feely, R. A., Gruber, N., Key, R. M., Lee, K., Bullister, J. L., Wanninkhof, R., Wong, C., Wallace, D. W., and Tilbrook, B.: The oceanic sink for anthropogenic $\mathrm{CO}_{2}$, Science, 305, 367-371, 2004.

Schmiedl, G., Mackensen, A., and Müller, P.: Recent benthic foraminifera from the eastern South Atlantic Ocean: dependence on food supply and water masses, Mar. Micropaleontol., 32, 249 287, 1997.

Ter Kuile, B. and Erez, J.: Carbon budgets for two species of benthonic symbiont-bearing foraminifera, Biol. Bull., 180, 489-495, 1991.

Toyofuku, T., Jan de Nooijer, L., Yamamoto, H., and Kitazato, H.: Real-time visualization of calcium ion activity in shallow benthic foraminiferal cells using the fluorescent indicator Fluo-3 AM, Geochem. Geophy. Geosy., 9, Q05005, https://doi.org/10.1029/2007GC00177, 2008.

Toyofuku, T., Matsuo, M. Y., de Nooijer, L. J., Nagai, Y., Kawada, S., Fujita, K., Reichart, G. J., Nomaki, H., Tsuchiya, M., Sakaguchi, H., and Kitazato, H.: Proton pumping accompanies calcification in foraminifera, Nat. Commun., 8, 14145, https://doi.org/10.1038/ncomms14145, 2017.

Uppström, L. R.: The boron/chlorinity ratio of deep-sea water from the Pacific Ocean, Deep Sea Research and Oceanographic Abstracts, 21, 161-162, 1974.

Uthicke, S. and Fabricius, K. E.: Productivity gains do not compensate for reduced calcification under near-future ocean acidification in the photosynthetic benthic foraminifer species Marginopora vertebralis, Glob. Change Biol., 18, 2781-2791, https://doi.org/10.1111/j.1365-2486.2012.02715.x, 2012.

Uthicke, S., Momigliano, P., and Fabricius, K.: High risk of extinction of benthic foraminifera in this century due to ocean acidification, Sci. Rep.-UK, 3, 1769, https://doi.org/10.1038/srep01769, 2013.

van Dijk, I., Bernhard, J. M., de Nooijer, L. J., Nehrke, G., Wit, J. C., and Reichart, G.-J.: Combined impacts of ocean acidification and dysoxia on survival and growth of four agglutinating foraminifera, J. Foramin. Res., 47, 294-303, 2017.

Wantland, K. F.: Recent benthonic foraminifera of the British Honduras shelf, Rice University, Houston, TX, 1967.

Zeebe, R. E. and Sanyal, A.: Comparison of two potential strategies of planktonic foraminifera for house building: $\mathrm{Mg}^{2+}$ or $\mathrm{H}^{+}$ removal?, Geochim. Cosmochim. Ac., 66, 1159-1169, 2002. 